УДК $821.161 .2-1.09^{\prime} 06$

\author{
Веретейченко I. А., \\ кандидат філологічних наук, доцент \\ Д3 «Луганський національний \\ університет імені Тараса \\ Шевченка» (м. Старобільск)
}

\title{
МІФОЛОГІЧНЕ КОРІННЯ ОБРАЗУ МІСТА В НЕОКЛАСИКІВ
}

Статтю присвячено дослідженню проиесу розвитку художнього образу міста поетами-неокласиками. Визначаються естетичні складові образу міста як суб'єкту перехідного прочесу. Аналізується специфіка естетичного сприйняття міста в різні епохи та взаємовідношення естетичного і художнього в структурі образу. Звернення до античних та християнських традицій дало можливість розкрити образ міста як модель буття. Це дозволило оновити психолого-інтуїтивне відчуття власне авторської екзистениії в умовах суперечливої дійсності 20-30-х років ХХ століття.

Ключові слова: неокласики, неокласииизм, місто, міфр, античність.

Статья посвящена исследованию прочесса развития художественного образа города поэтами-неоклассиками. Выделяются эстетические слагаемые образа города как субъекта переходного прочесса. Анализируется специфика эстетического восприятия города в разные эпохи и взаимоотношения эстетического и художественного в структуре образа. Обращение к античным и христианским традициям дало возможность раскрыть образ города как модель бытия. Это позволило обновить психолого-интуитивное ощущение собственно авторской экзистенции в условиях противоречивой действительности 20-30-х годов ХХ века.

Ключевые слова: неоклассики, неоклассищизм, город, миф, античность.

The article is devoted by investigation in development of an artistic image of city in the works of neoclassic poets. Aesthetic composed an image of city as subject of transient are defined. Specificity of aesthetic perception of city during different epoch and relationships of an aesthetic and art in image structure is analyzed. Ancient and Christian traditions helped to represent the image of city as the worldview. It allowed renovating its psychological and intuitive sense of existentialism of the author in controversial reality 20-30th of the XXth century.

Key words: neoklassyky, neoklassytsyzm, city, myth, antiquity 
На сьогодні місто варто розглядати як геосоціокультурну систему, що має територіально-географічний, архітектурно-планувальний, соціальноекономічний, культурно-інформаційний виміри. При цьому враховується роль міста як центру впливу та його ідентифікаційна функція, а також роль міста у формуванні різного роду взаємопов'язаних просторів: комерційного, соціального, рекреаційного, а відповідно й культурного тощо. Звідси метою розвідки $є$ різноаспектне дослідження європейської концепції образу міста, його ідейно-тематична своєрідність та принципи художньої організації.

Висвітленню цього питання були присвячені праці таких науковців, як М. Вебера, Г. Зіммеля, М. Бютора, К. Лінча, Л. Мамфорда, Р. Барта, Я. Мукаржовського, Жака ле Гофа, У. Еко, Ю. Лотмана, В. Топорова, Ю. Манна, Н. Шмідт, І. Мітіна, Р. Адамса, Ф. Броделя, Г. Сайко, С. Сассен, Ф. Тенніса, проаналізувавши які, можна стверджувати, що 3 часів Давньої Греції й Риму європейська художня думка знаходила й шліфувала притаманні їй мистецькі форми, закладала підмурівок інтелектуальної вежі, звідки загальноєвропейське місто та буттєві його околиці бачаться набагато виразніше. Визначається, що сформований при цьому “образ міста” і реальне його наповнення в художньому творі не завжди ідентифікуються, бо наукові й літературні узагальнення самопідтверджуються не дійсністю, якою та була, а результатами руху останньої убік сьогодення. Спираючись на дослідження Е. Ауербаха, О. Шпенглера визначається, що світова література - це література міська, “світових столиць”, яка розглядається на рівні міфології, символіки та семіотики тощо. Тому метою статті є розкрити особливості змалювання міста поетами-неокласиками, що виступило як новаторський фактор в українській літературі XX століття.

Польський літературознавець Я. Парандовський зазначав: «Письменник, поки молодий, переважно тримається міста, бо місто сприяє його духовному розвитку, невтомно стимулює творчість...» [Парандовский 1990:83]. Це можна поширити й на творчість “неокласиків”, які прийшли до літературної творчості “підготовленими”: «Вони були дітьми міста, точніше дітьми 
університетів і бібліотек, які можливі тільки в місті» [Павличко 1997:208]. Згодом вони стали поетами-дослідниками, архівістами, укладачами словників і колекціонерами документів. На думку ж одного 3 В. Домонтовича, творчість неокласиків вказувала на «внутрішню послідовність: на прагнення сполучити класичний філологізм з украӥнським традиціоналізмом, студї античности з'єднати із замилуванням в украӥнському бароко» [Домонтович 2000:81].

Формуючись під впливом світових культурних традицій, поети у своїм творах корінням сягала українських першоджерел. На це опосередковано вказує Е. Соловей, виводячи феноменологічні первні топосу міста в “неокласиків” від антитези “село - місто" в поезії П. Куліша, у якого звучить «поетична проповідь усамітнення, зосередженості, як оскарження метушні $i$ тлуму 3 їхніми низькими пристрастями» [Соловей 1998:100]. Вичерпну характеристику міста як історичного феномена представила С. Павличко, назвавши місто “неокласиків" «не просто темою, топосом чи типом пейзажу», а «символом певного типу свідомості як автора, так $і$ його героя» [Павличко 1997:84]. Таким чином, авторка вбачає в образі міста цих поетів своєрідну модель світу.

Такий дискурс стосовно феномена міста - логічне продовження дискусії, започаткованої Ю. Шерехом про певний внутрішній конфлікт урбанізму “неокласиків”. Критик стверджував: «вони наскрізь урбаністичні, але їхній urbs ӥх не приймав, бо він був російський [...] вони писали мовою села, якого не могли прийняти» [Шерех 1948: 67]. В де якійсь мірі можна стверджувати, що міська ж лірика неокласиків, а особливо М. Драй-Хмари з'являється під впливом творів про місто бельгійця Е. Верхарна та росіянина В. Брюсова з їх романтизацією i сприйняттям сучасного індустріалізованого міста як “незвичайного", “таємничого”, “дивного”, «якогось фантастичного світу» [Жирмунский 1996]. Особливо показова у цьому плані поема “Поворот”, де автор, протиставляючи праведне життя світовому розкішному (подібно до Сіону, міста небесного, і Вавилону - міста розкоші та розпусти), засвідчує епізод найдавнішої космогонії про боротьбу світла й темряви. Роль цієї антитези полягає у відтворенні індивідуальної концепції буття, що акцентує увесь сенс на духовному зв'язку 
божественного та людського начал у самій ідеї міста, адже кожен поет, вдаючись до зображення цивілізованого світу, передає його архетипно, але «на більи високому, космічному рівні» [Элиаде 1987:36].

Орієнтуючись на об’єктивізацію прекрасного, неокласики смислотворчою домінантою обирають місто, де відбувається часопросторове поєднання різних культурно-історичних досконалих форм. Місто для неокласиків - це підсумок безперервної творчої діяльності кожного, хто живе в ньому, це матеріальне втілення творчих поривів людини, своєрідна квінтесенція духовного життя народу, код, в якому зашифровані всі етапи його розвитку, спроби створення гармонійної культури. Саме образ міста складає глибинний шар художнього змісту в поетичній творчості неокласиків. Отже, місто для неокласиків постає не як статична, застигла форма, а як, скористаймося словами О. Шпенглера, “подовженість” і як вічне становлення [Шпенглер 1993].

Так у своїх творах неокласики розробляють християнський міф про походження Києва як від хреста Андрія Первозванного, благословення якого є запорукою святості матері міст руських. Це звучить у циклі М. Зерова “Київ”, а також у таких його сподвижників, як: М. Драй-Хмара (“Київ”), Ю. Клим (“Софія”), П. Филипович (“Київ”). І сьогодні - і образ апостола, і подія існують як сповна історичний факт. Загалом саме неокласики змінили і збагатили традиційне розуміння моделі світобудови в українській літературі - степ, поле i хутір - ввівши нову структуру - місто. Символ міста разом із Храмом, Домом виступає у творчості неокласиків центром світу. Це статус Києва як вічного світового міста. Вічність - ідеалістичне буття в урбаністичній поезії неокласиків набуває ознак класичного міста-утопії i М. Зеров знаходить прообрази в культурному матеріалі античності. В образі міста втілена в будь-якій своїй формі культура, яка є проривом у вічність. Образом вічності в поезії митців є Київ. Місто, якому долею визначена особлива роль в історії і культурі, живе за особливими законами і не тільки відтворює культуру, а й формує іiі. Це місто метафізичне, в архітектурі якого прочитуються ті основи, на яких грунтується розвиток культури і людини. 
У 20-х роках поети звертаються до епохи середньовіччя, провідними стали образи вежі, собору. У цьому плані слушна думка М. Еліаде, який виокремлює місто, храм і дім як головні елементи, чия «реальність $\epsilon$ складником символіки надземного цчентру, щзо уподібнює їх собі й перетворює на изентри свіmy» [Элиаде 1987:33]. Так, наприклад, в творчій уяві М. Драй-Хмари мінарет постає як велична споруда серед оголеного простору. Говорячи про сучасний Кам’янець, автор наголошував на приналежності його до світу високої культури; стверджував думку про “всевладність” будівлі, що «переборювала спротив простору» [Домонтович 2000:76]:

Яка застиглість і суворість форм!

Яка довершеність пропорцій, норм!

Поема, вирізьблена із граніту [Драй-Хмара 1989:123].

Проте крізь темні отвори середньовічних веж поетові увижаються “і кров, і гвалт, і заграви пожеж”. Місто вже розглядається наслідком діяльності новітніх Геростратів. У цьому сенсі М. Драй-Хмара, як і інші “неокласики”, виявився послідовником німецького культуролога та історика О. Шпенглера, який розглядав розвиток світових цивілізацій за циклічним принципом зародження, розквіту та занепаду. Саме від нього починається історична лінія тяглості мотиву «минулого золотого або геройчного віку, тисячоліття $у$ майбутньому [...] медитаџіï над руїнами, або ностальгія за минулою пасторальною простотою» [Слово. Знак. Дискурс 1996:131].

Також доречно звернути увагу на сонет “Олександрія”. Тут давньогрецькі мотиви наповнюють поезію М. Зерова особливими, неповторними картинами. В першому катрені постає дивовижний світ, що чекає на мандрівника:

Згасає день, і море вечоріє,

Пасатий вітер нам вітрило рве,

I чорний корабель спішить - пливе

До портових огнів Олександрії [Зеров 1990:60].

Пейзажна замальовка репрезентує місце та час дії твору. Епітет “пасатий вітер” доповнює барвистість морської картини. А займенник “нам” наближає 
реципієнта до основоположної глибини авторської думки. Кожен рядок твору цілеспрямовано проектує процес зростання психологічних переживань, пов'язаних з поверненням до рідних берегів. Весь мікросвіт, що оточує митця, перебуває в очікуванні дива, яке має з'явитися за лічені хвилини. I вже наступний катрен ніби вибухає своєрідним античним дивосвітом:

Он в сутіні велике місто мріє,

Двигтить і дихає, немов живе [Зеров 1990:60].

Саме таким постає місто міфів, легенд, образів-героїв. I не дивно, що, вималювавши його в своїй уяві, поет не в силі стримати захоплюючі вигуки:

О серце світу, муз житло нове,

Наш Геліконе, наша Пієріє! [Зеров 1990:60].

Так, вважає М. Зеров, вітали місто давньогрецькі мореплавці, що після тривалих мандрувань поверталися додому. Проте почуття людини, яка повернулася на рідну землю, не заважають поету бачити реальність, і він, вже вкотре, виступає суворим аналітиком минулої і сучасної йому пори. Неокласик не намагається ідеалізувати античність. Він сприймає та трактує минуле 3 позицій історичної перспективи культурних та технічних цінностей, часто в світі античності знаходячи витоки сучасних проблемних питань.

I в цьому неокласики люди свого часу, наповненого фаустівським духом вічного пізнання і прагненням вийти за межі. Останнє характеризує їх як митців, орієнтованих на класику взагалі, а не тільки на античність, як “людей культури". Можна говорити, що неокласики в якійсь мірі захоплювались архітектурою міста. В ній вони вбачали синтез всіх людських знань, творче будівниче начало. Тому неокласики називають i себе “математиками", “інженерами”, “архітектами”, “поетами” (М. Рильський “Поетові”). Це своєрідний синонімічний ряд. Вступаючи між собою в послідовний зв'язок і одночасно поєднуючись в образі поета, висвічує різні грані його онтологічної сутності. Так, поет як “математик” - носій гармонії, як “інженер” - такий, хто матеріалізує гармонію світу як сукупність людської діяльності, іiі майстерності, як “архітект” життєбудівничий. Для неокласиків “архітект” $\mathrm{i}$ “поет” $\epsilon$ 
величинами рівнозначними, втіленням вічного творчого начала. У такому розумінні образу поета неокласики традиційні, бо яскравий приклад цьому осанна, виспівана Гете архітектору Штейнбаху, будівникові Страсбурзького собору, який поклав початок готиці. Гете робить екскурс у минуле, показуючи, який колосальний шлях здійснило людство від халупи до готичного собору [Гете 1980].

Місто - явище матеріальної культури - для поетів постає духовним світом і осмислюється в руслі філософської традиції, де духовне є єдністю гносеологічного, етичного і естетичного моментів у житті і творчості (iстина, добро, краса). Саме через це вимальовується тріада українського неокласицизму - матеріальне (фізичне) - душевне (емоційний відгук) - духовне (ідея).

Виходячи з усього вище сказаного, можна висловити думку, що кожен поет “п’ятірного грона” репрезентував власний образ міста. Це можна довести на основі спільного й одного 3 найчастіше вживаних ними образів-топосів національного походження, означеного В. Зваричем «містом зі світовим статусом, “градом” Вічності ци Краси» [Зварич 2002:15]. Цілком у дусі “неокласиків” був особливий пієтет у ставленні до Києва як до наймогутнішого осередку культурно-історичного потенціалу. Саме тому Є. Маланюк зазначав: «Чи київський письменник писав по-російськи, чи по-польськи, - на творчості його лежала печать передовсім “Києва” [...] “Київська Александрія” дала грунт і створила “клімат” для української неокласики 1918-1928 років» [Маланюк 1997:252]. Для М. Зерова, автора сонета “Київ з лівого берега”, слава Києва в минулому, він лише сподівається на повернення «щцасливой миті буяння, цвіту $і$ держави» [Зеров 1990:27]. Тож М. Зеров не приймав сучасність, оскільки, як зауважив Ю. Шерех, вона була йому внутрішньо чужа. Юрій Клен також ідеалізував минуле, активно заперечуючи сучасне, наприклад, в описі Софії Київської.

Урбаністичні мотиви в художній спадщині неокласиків набули нових драматичних відтінків; образ міста у них став тим естетичним кодом, що не 
лише відтворює існуючу модель світу, а й оновлює іiі психолого-інтуїтивним відчуттям власне авторської екзистенції в умовах суперечливої дійсності 20-30-х років XX століття і водночас сприймається як перспектива культури майбутнього.

Таким чином, пафос міфологізму неокласиків виявляє негативи й позитиви буттєвих начал. Онтологічна “заміна” реальної дійсності власною міфологічною моделлю світу здійснюється поетами за допомогою багатьох чинників. Серед них на особливий статус заслуговують міфологічні алюзії, міфологічний модус більшості тропів тощо.

\section{БІБЛІОГРАФІЯ}

Гете 1980 - Гете И. В. О немецком зодчестве [Текст] / И. В. Гете // Гете И. В. Собр. соч. в 10 т. - М. : Высшая школа, 1980. - Т.10. - 344 с.

Домонтович 2000 - Домонтович В. Київський університет і становлення українського неокласицизму / В. Домонтович // Народна творчість та етнографія. - 2000. - № 4. - С. 75-84.

Драй-Хмара 1989 - Драй-Хмара М. Вибране / М. Драй-Хмара / Упор. Д. Паламарчука, Г. Кочура ; Передм. І. Дзюби. - К. : Дніпро, 1989. - 542 с.

Элиаде 1987 - Элиаде М. Космос и история : Избр. работы / М. Элиаде. М. : Прогресс, 1987. - 312 с.

Жирмунский 1996 - Жирмунский В.М. Введение в литературоведение: Курс лекций / В. М. Жирмунский / Под ред. З. И. Плавскина, В. В. Жирмунской. - СПб. : Изд-во С.-П. ун-та, 1996. - 440 с.

Зварич 2002 - Зварич В. Стилетворчі функції традиційних образів у поезії неокласиків: Автореф. дис. ... канд. філол. наук : 10.01 .01 / В. Зварич/ Тернопільський держ. пед. ун-т. - Тернопіль, 2002. - 20 с.

Зеров 1990 - Зеров М. Твори : В 2 т. / М. Зеров / Упорядн. Г. П. Кочур, Д. В. Павличко. - К. : Дніпро, 1990. - Т. 1. - 843 с.

Маланюк 1997 - Маланюк Є. Київська Александрія / Є. Маланюк // Маланюк С. Книга спостережень. Статті про літературу. - К. : Дніпро, 1997. C. $246-253$. 
Павличко 1997 - Павличко С. Дискурс модернізму в українській літературі / С. Павличко. - К. : Либідь, 1997. - 360 с.

Парандовский 1990 - Парандовский Я. Алхимия слова / Я. Парандовский / Сост. и вступ. ст. С. Бэлзы. - М. : Правда, 1990. - 656 с.

Слово. Знак. Дискурс. 1996 - Слово. Знак. Дискурс. Антологія світової літературно-критичної думки ХХ ст. (За ред. М.Зубрицької). - Львів, 1996. 633 c.

Соловей 1998 - Соловей Е. Українська філософська лірика / Е. Соловей. К. : ІПніверс, 1998. - 368 с.

Шерех 1948 - Шерех Ю. Думки проти течії. Публіцистика / Ю. Шерех. Видавництво Україна, 1948. - 100 с. 